\title{
Pengaruh Pendidikan Kesehatan Perawatan Kaki Diabetik dengan Metode Demonstrasi Terhadap Kemampuan Merawat Kaki Pada Pasien Diabetes Mellitus
}

\author{
Rina Sari Dewi Setyaningsih ${ }^{1}$, Arina Maliya ${ }^{2 *}$ \\ ${ }^{1}$ Program Studi Ilmu Keperawatan Universitas Muhammadiyah Surakarta, Kartasura, 57162, Jawa \\ Tengah, Indonesia. \\ 2Departemen Keperawatan Medikal Bedah, Program Studi Ilmu Keperawatan Universitas \\ Muhammadiyah Surakarta, Kartasura, 57162, Jawa Tengah, Indonesia. \\ *Korespondensi: Arina.Maliya@ums.ac.id
}

\begin{abstract}
Abstrak: Diabetes Mellitus (DM) sering menimbulkan komplikasi berupa stroke, gagal ginjal, gagal jantung, nefropati, kebutaan dan bahkan harus menjalani amputasi. Masalah cidera kaki diabetes di Indonesia sampai saat ini masih menjadi masalah yang kompleks, karena angka kematian dan angka amputasi masih tinggi. Salah satu penatalaksanaan DM adalah dengan edukasi. Tujuan Penelitian adalah untuk mengetahui pengaruh pendidikan kesehatan terhadap perawatan kaki diabetik dengan metode demonstrasi pada penderita diabetes mellitus. Metode Penelitian yaitu Pre-experimental design dengan pendekatan Intact-Group Comparison.Teknik sampel non probability sampling dengan tehnik purposive sampling sebanyak 30 responden. Hasil Penelitian menyatakan bahwa tingkat pengetahuan rata- rata sebelum pendidikan kesehatan adalah 12.766 dan setelah penyuluhan 15.166 atau meningkat 3.60 lebih baik. Kemampuan penderita diabetes mellitus merawat kaki sebelum diberikan pendidikan kesehatan nilai rata-rata adalah 4.666 dan kemampuan penderita diabetes mellitus dalam merawat kaki setelah diberikan pendidikan kesehatan dengan rata-rata 8.133. Kesimpulannya yaitu ada pengaruh pendidikan kesehatan terhadap perawatan kaki diabetik dengan metode demonstrasi dapat meningkatkan kemampuan merawat kaki diabetik sebanyak 3.466 dari sebelum demonstrasi.
\end{abstract}

Kata kunci: Pendidikan Kesehatan, Demonstrasi, Kaki diabetik.

Abstract: The disease of DM complications often form of stroke, kidney failure, heart, nephropathy, blindness and even had to undergo amputation. The problem of diabetes leg injury in Indonesia to date is still a complex issue, because the mortality rate and the amputation is still high. One of the treatment DM was with education. Research objectives to find out the influence of health education against diabetic foot treatment with the method of demonstration in diabetics mellitus patients. The research was included in this type of Pre-experimental design with Intact-Group Comparison approach. Enginering samples are non probability sampling with technical purposive sampling of as many as 30 respondents. The average level of knowledge prior to health education is 12.766 and after extension or increased 15,166 better. The ability of people with diabetes mellitus care for leg before given health education the average rating is 4,666 and the ability of people with diabetes mellitus in taking care of feet after a given health education with an average 8,133. The summary is the influence of health education against diabetic foot treatment with demonstration methods can improve the care of diabetic foot as much as 3,466 from before the demonstration.

Keywords: Health education, demonstrations, Diabetic Foot 


\section{PENDAHULUAN}

Diabetes Mellitus (DM) adalah suatu sindrom klinis kelainan metabolik dengan ditandai oleh adanya hiperglikemia yang disebabkan oleh defek sekresi insulin, defek kerja insulin atau keduanya. Penyakit DM sering menimbulkan komplikasi berupa stroke, gagal ginjal, jantung, nefropati, kebutaan dan bahkan harus menjalani amputasi jika anggota badan menderita luka gangren. DM yang tidak ditangani dengan baik angka kejadian komplikasi dari DM juga akan meningkat, termasuk komplikasi cidera kaki diabetes (Waspadji, 2010).

Komplikasi dari Diabetes Mellitus yang sering adalah ulkus diabetes, beberapa faktor secara bersamaan berperan terjadinya ulkus diabetes. Di mulai dari faktor pengelolaan penderitan Diabetes penyakitnya yang kurang baik, adanya neuropati perifer, dan autonom. Faktor komplikasi vaskuler yang memperburuk aliran darah ke kaki tempat luka, faktor kerentaan terhadap infeksi akibat respon kekebalan tubuh yang menurun pada keadaan Diabetes Mellitus tidak terkendali, serta faktor ketidaktahuan pasien (Suyono, 2007).

Berdasarkan bukti epidemologi terkini, jumlah penderita Diabetes Mellitus di seluruh dunia saat ini mencapai 200 juta, dan di perkirakan meningkat lebih dari 330 juta pada tahun 2025. Alasan peningkatan ini termasuk meningkatnya angka harapan hidup dan pertumbuhan populasi yang tinggi, dua kali lipat disertai peningkatan angka obesitas yang di kaitkan dengan urbanisasi dan ketergantungan terhadap makanan olahan. The Journal of American Medical Association (JAMA), diabetes berkembang di Asia dan menjadi dilema global. Jurnal tersebut mengemukakan statistik terbaru dugaan pertumbuhan penderita diabetes meningkat dari 240 juta pasien di tahun 2007 menjadi 380 juta pasien di tahun 2025. Lebih dari 60 $\%$ kasus ini akan terjadi di Asia. Berdasarkan data dari Dinas Kesehatan Provisinsi Jawa Tengah pada tahun 2013 - 2014 Diabetes Mellitus tipe II menempati urutan ke 5 dari 15 penyakit yang tidak menular di Jawa Tengah. Pada tahun 2013 penderita Diabetes Mellitus sebanyak 200.297 (17\%) jiwa dari jumlah penduduk keseluruhan 32.380.279 jiwa. Pada tahun 2014 penderita penyakit Diabetes Mellitus sebanyak 245.907 jiwa, 18\% dari jumlah penduduk keseluruhan 32.380.687 jiwa dan pada tahun 2009 penderita Diabetes Mellitus sebanyak 249.181 jiwa, 13\% dari jumlah penduduk keseluruhan 32.381.390 jiwa (DinKes Jawa Tengah, 2015).

Prevalensi tersebut meningkat 2-3 kali dibandingkan dengan negara maju, bahkan Indonesia menempati urutan terbesar ke-4 dalam jumlah penderita diabetes mellitus dengan prevalensi $8,6 \%$ dari total penduduk. Hasil ini menujukkan bahwa Diabetes mellitus merupakan masalah kesehatan masyarakat yang serius. Apabila tidak ditangani dan dicegah secara tepat dan kontinyu, maka hal ini akan dapat mempengaruhi ketahanan ekonomi nasional karena DM bersifat kronis dan mempengaruhi produktivitas. Komplikasi akut DM seperti hipoglikemi dan hiperglikemi dapat terjadi dalam perjalanan penyakit DM dan merupakan keadaan gawat darurat yang dapat menyebabkan kematian. Komplikasi jangka panjang DM termasuk retinopati, nefropati, neuropati otonom dan neuropati perifer dengan resiko ulkus kaki dan amputasi. Berdasarkan data dari National Diabetes Fact Sheet (2011), sekitar 60\% - 70\% penderita diabetes mengalami komplikasi neuropati tingkat ringan sampai berat yang akan berakibat pada hilangnya sensori dan kerusakan ekstremitas bawah. Ulkus kaki diabetes merupakan penyebab utama (85\%) dari seluruh amputasi pada ekstremitas bawah (Misnadiarly, 2006).

Data ini diperkuat oleh WHO yang menyebutkan bahwa amputasi tungkai terjadi 10 kali lebih banyak pada penderita diabetes dibandingkan yang bukan penderita diabetes. Empat pilar penatalaksanaan diabetes yaitu edukasi, terapi gizi nutrisi, latihan jasmani, dan terapi farmakologi. Pengetahuan yang kurang tentang perawatan diri, terutama perawatan kaki menjadi hambatan bagi pasien untuk melakukan perawatan kaki. Oleh karena itu, edukasi sangat penting dilakukan agar komplikasi jangka panjang dapat dicegah. Perilaku perawatan kaki, kepercayaan diri, dan pengetahuan pasien serta keluarga terhadap penyakit Diabetes Mellitus tipe II dapat meningkat setelah diberikan edukasi perawatan kaki serta dapat mencegah terjadinya ulkus kaki diabetik(Perkeni, 2015).

Terdapat beberapa metode pendidikan kesehatan yang dapat digunakan untuk mengimplementasikan strategi pembelajaran antara lain ceramah, seminar, tanya jawab, diskusi, simulasi, brainstorming, dan demonstrasi. Metode demonstrasi merupakan metode pembelajaran tentang suatu prosedur dan belajar berinteraksi yang dapat dilakukan secara langsung melalui alat peraga (Rakhmat, 
2011).

Berdasarkan studi pendahuluan yang dilakukan di Rumah Sakit Soeradji Tirtonegoro Klaten, jumlah penderita ulkus DM tipe II pada pasien rawat jalan selama periode kunjungan bulan Januari - Mei 2016 mengalami peningkatan, dengan rata-rata sebanyak 310 pasien setiap bulan. Pasien DM yang mengalami ulkus DM sebanyak 30 (9,67\%). Berdasarkan hasil wawancara dengan 2 perawat dan10 orang penderita DM, menyatakan bahwa pasien yang berobat ke instalasi rawat jalan sudah pernah mendapatkan pendidikan kesehatan tentang perawatan kaki diabetik dengan metode ceramah tetapi belum pernah mendapatkan pendidikan kesehatan tentang perawatan kaki diabetik dengan metode demonstrasi.

Penelitian ini secara umum bertujuan untuk mengetahui pengaruh pendidikan kesehatan trerhadap perawatan kaki diabetik dengan metode demonstrasi pada penderita diabetes mellitus di RSUP Dr. Soeradji Tirtonegoro Klaten.

\section{METODE}

Jenis penelitian yang digunakan dalam penelitian ini adalah Pre- experimental design dengan pendekatan Intact-Group Comparison. Desain ini bertujuan mengidentifikasikan hubungan sebab akibat dengan cara melibatkan kelompok kontrol disamping kelompok eksperiment yang mendapatkan perlakuan yaitu pendidikan kesehatan perawatan kaki diabetik dengan metode demonstrasi terhadap kemampuan merawat kaki pada pasien diabetes mellitus di Poliklinik Penyakit Dalam RSUP Dr. Soeradji Tirtonegoro Klaten (Notoatmodjo, 2010). Populasi dalam penelitian ini adalah pasien Diabetes Mellitus yang memeriksakan kesehatan di Poliklinik Penyakit Dalam RSUP Dr. Soeradji Tirtonegoro Klaten. Pengambilan sampel dalam penelitian ini dilakukan secara non probability sampling dengan teknik purposive sampling, yaitu pengambilan sampel didasarkan pada suatu pertimbangan tertentu yang dibuat oleh peneliti sendiri berdasarkan ciri atau sifat populasi yang sudah diketahui sebelumnya. Jumlah sampel pada penelitian ini sebanyak 30 responden (Sugiyono, 2012). Penelitian ini menggunakan alat ukur kuesioner pengetahuan dan lembar observasi perawatan kaki diabetik. Analisa data pada penelitian ini menggunakan uji Paried T Test.

\section{HASIL}

Karakteristik Responden

Tabel 1. Distribusi frekuensi jenis kelamin

\begin{tabular}{ccccc}
\hline Jenis Kelamin & \multicolumn{2}{c}{ Kelompok Kontrol } & \multicolumn{2}{c}{ Kelompok Perlakuan } \\
\hline & Frekuensi & Prosentase (\%) & Frekuensi & Prosentase (\%) \\
\hline Laki-laki & 5 & 16,6 & 5 & 16,6 \\
Perempuan & 10 & 33,3 & 10 & 33,3 \\
\hline Total : & 15 & 50 & 15 & 50 \\
\hline
\end{tabular}

Tabel 2. Distribusi frekuensi umur

\begin{tabular}{ccccc}
\hline Umur & \multicolumn{2}{c}{ Kelompok Kontrol } & \multicolumn{2}{c}{ Kelompok Perlakuan } \\
\hline & Frekuensi & Prosentase (\%) & Frekuensi & Prosentase (\%) \\
\hline $20-40$ & 0 & 0 & 2 & 6,6 \\
$41-60$ & 13 & 43,3 & 12 & 40,0 \\
$>60$ & 2 & 6,6 & 1 & 1,7 \\
\hline Total : & 15 & 50 & 15 & 50 \\
\hline
\end{tabular}


Tabel 3. Distribusi frekuensi pendidikan

\begin{tabular}{ccccc}
\hline \multirow{2}{*}{ Pendidikan } & \multicolumn{2}{c}{ Kelompok Kontrol } & \multicolumn{2}{c}{ Kelompok Perlakuan } \\
\cline { 2 - 5 } & Frekuensi & Prosentase $(\%)$ & Frekuensi & Prosentase $(\%)$ \\
\hline SD & 6 & 20,0 & 5 & 16,6 \\
SMP & 0 & 0 & 3 & 10,0 \\
SMA & 9 & 30,0 & 3 & 10,0 \\
Diploma / PT & 0 & 0 & 4 & 13,3 \\
\hline Total & 15 & 50 & 15 & 50 \\
\hline
\end{tabular}

\section{Analisis Univariat}

Tabel 4. Distribusi Frekuensi Pengetahuan

\begin{tabular}{ccccccc}
\hline Kategori & \multicolumn{2}{c}{ Kelompok Kontrol } & \multicolumn{2}{c}{ Kelompok Perlakuan } & $X$ & SD \\
\hline $\begin{array}{c}\text { Tingkat } \\
\text { Pengetahuan }\end{array}$ & Frekuensi (f) & $\begin{array}{c}\text { Prosentase } \\
(\%)\end{array}$ & $\begin{array}{c}\text { Frekuensi } \\
(\mathrm{f})\end{array}$ & $\begin{array}{c}\text { Prosentase } \\
(\%)\end{array}$ & & \\
\hline Baik & 12 & 40 & 15 & 50 & 11.60 & 2.26 \\
Kurang & 3 & 10 & 0 & 0 & 0 & 8 \\
\hline
\end{tabular}

Tabel 5. Distribusi Frekuensi Pengetahuan

\begin{tabular}{ccc}
\hline Pengetahuan & $\bar{X}$ & SD \\
\hline Pre test & 12.766 & \pm 2.686 \\
Post test & 15.166 & \pm 3.322 \\
\hline
\end{tabular}

Table 6. Distribusi Frekuensi Perawatan Kaki Diabetik

\begin{tabular}{cccccc}
\hline No & Kategori & \multicolumn{2}{c}{ Pre Test } & \multicolumn{2}{c}{ Post Test } \\
\hline & $\begin{array}{c}\text { Perawatan Kaki } \\
\text { Diabetik }\end{array}$ & $\begin{array}{c}\text { Frekuensi } \\
(\mathrm{f})\end{array}$ & $\begin{array}{c}\text { Prosentase } \\
(\%)\end{array}$ & $\begin{array}{c}\text { Frekuensi } \\
(\mathrm{f})\end{array}$ & $\begin{array}{c}\text { Prosentase } \\
(\%)\end{array}$ \\
\hline 1 & Nilai 3 & 1 & 40 & 0 & 0 \\
2 & Nilai 4 & 7 & 23.3 & 0 & 0 \\
3 & Nilai 5 & 3 & 10.0 & 0 & 0 \\
4 & Nilai 6 & 4 & 13.3 & 0 & 0 \\
5 & Nilai 7 & 0 & 0 & 4 & 13.3 \\
6 & Nilai 8 & 0 & 0 & 5 & 16.6 \\
7 & Nilai 9 & 0 & 0 & 6 & 20 \\
\hline
\end{tabular}

Table 7. Distribusi Frekuensi Perawatan Kaki Diabetik

\begin{tabular}{|c|c|c|}
\hline Perawatan Kaki Diabetik & $\bar{X}$ & SD \\
\hline Pre test & 4.666 & \pm 0.975 \\
\hline Post test & 8.133 & \pm 0.833 \\
\hline
\end{tabular}


Analisis Bivariat

Table 8. Crosstabulation pengaruh pendidikan kesehatan dengan metode demonstrasi terhadap perawatan kaki diabetik

\begin{tabular}{lccc}
\hline Kelompok & - & & \\
& $\mathrm{X}$ & SD & P Value \\
\hline Pre test & \pm 4.666 & 3.466 & 0,673 \\
Post test & \pm 8.133 & & \\
\hline
\end{tabular}

\section{PEMBAHASAN}

\section{Karakteristik Responden}

Hasil penelitian menunjukan bahwa responden sebagian besar mempunyai jenis kelamin perempuan. Hasil penelitian ini berbeda dengan pendapat dari Damayanti (2015), yang menyatakan bahwa jenis kelamin laki-laki memiliki risiko diabetes meningkat lebih cepat. Para ilmuwan dari University of Glasgow, Skotlandia mengungkap hal itu setelah mengamati 51.920 laki-laki dan 43.137 perempuan. Seluruhnya merupakan pengidap diabetes tipe II dan umumnya memiliki indeks massa tubuh (IMT) di atas batas kegemukan atau overweight. Laki-laki terkena diabetes pada IMT rata-rata 31,83 $\mathrm{kg} / \mathrm{m} 2$ sedangkan perempuan baru mengalaminya pada IMT 33,69 kg/m2. Perbedaan resiko ini dipengaruhi oleh distribusi lemak tubuh.

Pada laki-laki, penumpukan lemak terkonsentrasi di sekitar perut sehingga memicu obesitas sentral yang lebih berisiko memicu gangguan metabolisme. Berdasarkan hasil penelitian responden sebagian besar adalah perempuan. Hal tersebut dikarenakan perempuan kurang melakukan aktifitas fisik. Kurangnya aktifitas merupakan salah satu faktor yang ikut berperan dalam menyebabkan resistensi insulin pada DM tipe II. Semakin jarang kita melakukan aktivitas fisik maka gula yang dikonsumsi juga akan semakin lama terpakai, akibatnya prevalensi peningkatan kadar gula dalam darah juga akan semakin tinggi.

Usia responden sebagian besar adalah pada usia 41-60 tahun, semakin usia bertambah semakin beresiko terkena penyakit Diabetes Mellitus. Hasil penelitian ini sependapat dengan Damayanti (2015) yang menyatakan bahwa DM tipe II biasanya terjadi setelah usia 30 tahun dan semakin sering terjadi setelah usia 40 tahun, selanjutnya terus meningkat pada usia lanjut. Goldberg dan Coon menyatakan Umur sangat erat kaitannya dengan terjadinya kenaikan kadar glukosa darah, sehingga semakin meningkat usia maka prevalensi diabetes dan gangguan toleransi glukosa semakin tinggi. Proses menua yang berlangsung setelah usia 30 tahun mengakibatkan perubahan anatomis, fisiologis dan biokimia. Perubahan dimulai dari tingkat sel, berlanjut pada tingkat jaringan dan akhirnya pada tingkat organ yang dapat mempengaruhi fungsi homeostasis. Komponen tubuh yang dapat mengalami perubahan adalah sel beta pankreas yang menghasilkan hormon insulin, sel-sel jaringan target yang menghasilkan glukosa, sistem saraf, dan hormon lain yang mempengaruhi kadar glukosa.

Tingkat pendidikan responden sebagian adalah SMA, semaikin tinggi pendidikan seseorang maka semakin beresiko lebih rendah terkena Penyakit Diabetes Mellitus. Tingkat pendidikan seseorang bisa menjadi faktor dalam sekresi insulin .Respon stress menyebabkan terjadinya sekresi sistem saraf simpatis yang diikuti oleh sekresi simpatis-medular, dan bila stress menetap maka sistem hipotalamus-pituitari akan diaktifkan dan akan mensekresi corticotropin releasingfactor yang menstimulasi pituitari anterior memproduksi adenocorticotropic faktor (ACTH). ACTH memstimulasi produksi kortisol, yang akan mempengaruhi peningkatan kadar glukosa darah. 


\section{Pengetahuan}

Berdasarkan hasil penelitian yang telah dilakukan peneliti dapat diketahui bahwa rerata tingkat pengetahuan responden adalah baik. Berdasarkan hasil penelitian yang telah dilakukan peneliti dapat diketahui bahwa distribusi frekuensi tingkat pengetahuan responden pada kelompok pre test minimum adalah 7.00 dan maximum adalah 18.00 dengan rat- rata adalah 12.766 sedangkan pada Post test meningkat menjadi minimum 9.00 dan maximum adalah 20.00 dengan rata-rata adalah 15.00 atau meningkat 3.60 lebih baik. Pendidikan kesehatan adalah suatu proses perubahan pada diri seseorang yang dihubungkan dengan pencapaian tujuan kesehatan individu dan masyarakat. Peningkatan pengetahuan ini karena adanya informasi kesehatan melalui pendidikan kesehatan. Hasil penelitian ini mendukung pendapat dari Notoatmodjo (2007) yang menyatakan bahwa pendidikan kesehatan bisa juga merupakan proses perubahan perilaku secara terencana pada diri individu, kelompok, dan masyarakat untuk dapat lebih mandiri dalam mencapai tujuan hidup sehat.

Pendidikan kesehatan merupakan proses belajar pada individu, kelompok atau masyarakat dari tidak tahu tentang nilai kesehatan menjadi tahu, dan dari tidak mampu mengatasi masalah kesehatan menjadi mandiri. Dengan demikian pendidikan kesehatan merupakan usaha atau kegiatan untuk membantu individu, kelompok, dan masyarakat meningkatkan kemampuan baik pengetahuan, sikap maupun keterampilan untuk mencapai hidup sehat secara optimal (Rakhmat, 2011).

Hasil penelitian ini sependapat dengan penelitian sebelumnya oleh Nida Faradisa (2012) hasil penelitian menunjukan bahwa terdapat hubungan antara pengetahuan pasien diabetes melitus tipe II tentang risiko terjadinya ulkus diabetik dengan kejadian ulkus diabetik di RSUD Dr. Moewardi dengan kolerasi yang lemah. Menurut penelitian Firma A (2014), menyatakan bahwa tingkat pengetahuan penderita DM dalam melakukan pencegahan luka kaki diabetik mayoritas sebelum mendapatkan pendidikan kesehatan tergolong cukup, sikap penderita DM dalam melakukan pencegahan luka kaki diabetik mayoritas sebelum mendapatkan pendidikan kesehatan tergolong baik, sikap penderita DM dalam melakukan pencegahan luka kaki diabetik mayoritas sebelum mendapatkan pendidikan kesehatan tergolong baik, sikap penderita DM dalam melakukan pencegahan luka kaki diabetik sesudah mendapatkan pendidikan kesehatan sebagian besar tergolong baik, terdapat pengaruh pemberian pendidikan kesehatan terhadap peningkatan sikap penderita DM dalam melakukan pencegahan luka kaki diabetik.

\section{Perawatan kaki diabetik}

Berdasarkan hasil penelitian yang telah dilakukan peneliti dapat diketahui bahwa rerata tingkat pengetahuan responden adalah baik. Berdasarkan hasil penelitian yang telah dilakukan peneliti dapat diketahui bahwa distribusi frekuensi tingkat pengetahuan responden pada kelompok pre test minimum adalah 7.00 dan maximum adalah 18.00 dengan rat- rata adalah 12.766 sedangkan pada Post test meningkat menjadi minimum 9.00 dan maximum adalah 20.00 dengan rata-rata adalah 15.00 atau meningkat 3.60 lebih baik. Pendidikan kesehatan adalah suatu proses perubahan pada diri seseorang yang dihubungkan dengan pencapaian tujuan kesehatan individu dan masyarakat. Peningkatan pengetahuan ini karena adanya informasi kesehatan melalui pendidikan kesehatan. Hasil penelitian ini mendukung pendapat dari Notoatmodjo (2007) yang menyatakan bahwa pendidikan kesehatan bisa juga merupakan proses perubahan perilaku secara terencana pada diri individu, kelompok, dan masyarakat untuk dapat lebih mandiri dalam mencapai tujuan hidup sehat.

Pendidikan kesehatan merupakan proses belajar pada individu, kelompok atau masyarakat dari tidak tahu tentang nilai kesehatan menjadi tahu, dan dari tidak mampu mengatasi masalah kesehatan menjadi mandiri. Dengan demikian pendidikan kesehatan merupakan usaha atau kegiatan untuk membantu individu, kelompok, dan masyarakat meningkatkan kemampuan baik pengetahuan, sikap maupun keterampilan untuk mencapai hidup sehat secara optimal (Rakhmat, 2011).

Hasil penelitian ini sependapat dengan penelitian sebelumnya oleh Nida Faradisa (2012) hasil penelitian menunjukan bahwa terdapat hubungan antara pengetahuan pasien diabetes melitus tipe II tentang risiko terjadinya ulkus diabetik dengan kejadian ulkus diabetik di RSUD Dr. Moewardi dengan kolerasi yang lemah. Menurut penelitian Firma A (2014), menyatakan bahwa tingkat pengetahuan penderita DM dalam 
melakukan pencegahan luka kaki diabetik mayoritas sebelum mendapatkan pendidikan kesehatan tergolong cukup, sikap penderita DM dalam melakukan pencegahan luka kaki diabetik mayoritas sebelum mendapatkan pendidikan kesehatan tergolong baik, sikap penderita DM dalam melakukan pencegahan luka kaki diabetik mayoritas sebelum mendapatkan pendidikan kesehatan tergolong baik, sikap penderita DM dalam melakukan pencegahan luka kaki diabetik sesudah mendapatkan pendidikan kesehatan sebagian besar tergolong baik, terdapat pengaruh pemberian pendidikan kesehatan terhadap peningkatan sikap penderita DM dalam melakukan pencegahan luka kaki diabetik.

\section{Pengaruh pendidikan kesehatan dengan metode demonstrasi terhadap perawatan kaki diabetik}

Hasil penelitian untuk mengetahui pengaruh pendidikan kesehatan dengan metode demonstrasi terhadap perawatan kaki diabetik Responden di Poliklinik Penyakit Dalam RSUP Dr. Soeradji Tirtonegoro Klaten dapat diketahui bahwa nilai $\mathrm{p}=0.001$ dan karena $\mathrm{p}<0.05$ maka Ho ditolak dan Ha diterima yang artinya terdapat pengaruh yang signifikan antara pendidikan kesehatan menggunakan metode demonstrasi terhadap perawatan kaki diabetik dengan rata- rata pada kelompok pre test 4.666 dan kelompok post test 8.133, sehingga dapat dilihat bahwa metode demonstrasi dapat meningkatkan kemampuan merawat kaki diabetik sebanyak 3.466 dari sebelum demonstrasi dan setelah demonstrasi. Secara statistik pengaruh pendidikan kesehatan dengan metode demonstrasi terhadap perawatan kaki diabetik mempunyai kekuatan hubungan 0.673 yang artinya hubungan kuat.

Jurnal penelitian internasional oleh Stacey (2015) menyatakan bahwa pengetahuan, perilaku, jenis kelamin dapat mempengaruhi perawatan kaki diabetik. Semakin tingkat pengetahuan tinggi maka akan semakin baik dalam melakukan perawatan kaki diabetik. Jenis kelamin laki-laki lebih baik dalam melakukan perawatan kaki diabetik dan dengan perilaaku yang baik maka perawatan kaki diabetik akan lebih baik.Pengetahuan dan sikap adalah merupakan respons seorang terhadap stimulus atau rangsangan yang masih bersifat terselubung, dan disebut "covert behavior". Sedangkan tindakan nyata seseorang sebagai respons seseorang terhadap terhadap stimulus (practise) adalah merupakan "overt behavior".

Hasil penelitian ini sependapat dengan Formosa (2012), yang berpendapat bahwa pentingnya peran tenaga kesehatan profesional dalam memeriksa dan menilai kaki diabetik, serta mendidik mereka yang mempunyai penyakit diabetes mellitus untuk melakukan pencegahan ulkus diabetik dengan melakukan perawatan kaki diabetik dengan baik. Dengan pendidikan kesehatan yang dilakukan perawat dalam cara mencegah kaki diabetik dapat meningkatkan pengetahuan tentang perawatan kaki diabetik sehingga bisa mengubah perilaku pencegahan kaki diabetik.

Hasil penelitian ini juga mendukung penelitian sebelumnya yang dilakukan oleh Louise (2016) yang menyatakan bahwa pendidikan kesehatan dengan latihan aktivitas dapat menurunkan masa lemak, meningkatkan fungsi sensorik, memperlancar vaskularisasi pada remaja yang menderita Diabetes mellitus tipe II. Penelitian yang dilakukan oleh peneliti menyatakan bahwa dengan dilakukan pendidikan kesehatan menggunakan metode demonstrasi dapat meningkatkan kemampuan merawat kaki diabetik.

Jurnal Massaki Miyauchi (2016) menyatakan bahwa managemen latihan terapi pada pasien diabetes mellitus type II dapat menurunkan kadar hemoglobin A1c (HbA1c). Jurnal ini mendukung hasil penelitian yang dilakukan oleh peneliti bahwa sikap dan perilaku dalam melakukan aktifitas secara teratur pada pasien diabetes mellitus akan mempengaruhi perawatan kaki diabetik.

Menurut jurnal internasional oleh Alaa (2012), yang menyatakan bahwa perawat berperan dalam promosi kesehatan dengan melakukan penyuluhan kesehatan mengenai perawatan kaki diabetik dapat meningkatkan pengetahuan pasien dan keluarga sehingga bisa menurunkan coz efective rawat inap.

Perilaku dipengaruhi oleh pengetahuan, sikap, kebiasaan, kepercayaan, norma sosial. Faktor pendukung antara lain pendidikan, status sosial ekonomi, umur, potensi dari masyarakat dan faktor pendorong antara lain pendapat orang yang disegani misalnya orang tua, tokoh masyarakat, petugas kesehatan (Green cit Notoatmodjo 2007).Faktor-faktor yang dapat mempermudah atau mempredisposisi terjadinya perilaku pada diri seseorang atau masyarakat, adalah pengetahuan dan sikap seseorang atau masyarakat tersebut terhadap apa yang akan dilakukan. Misalnya perilaku penderita Diabetes Mellitus untuk melakukan perawatan kaki diabetik akan dipermudah apabila penderita tersebut tahu apa manfaat perawatan kaki diabetik, tahu cara dan kapan perawatan kaki diabetik tersebut dilakukan. Demikian pula, 
perilaku tersebut akan dipermudah bila penderita Diabetes Mellitus yang bersangkutan mempunyai sikap yang positif terhadap perawatan kaki diabetik. Di samping itu, kepercayaan, tradisi, sistem, nilai di masyarakat setempat juga menjadi mempermudah (positif) atau mempersulit (negatif) terjadinya perilaku seseorang atau masyarakat. Kepercayaan bahwa penyakit Diabetes Mellitus merupakan penyakit keturunan dan tidak bisa disembuhkan, dengan sendirinya akan menghambat perilaku penderita Diabetes Mellitus untuk pasrah (negatif). Dengan adanya pendidikan kesehatan oleh tenaga kesehatan RSUP dr Soeradji Tirtonegoro Klaten dapat meningkatkan pengetahuan sebanyak 3.60 lebih baik dari sebelum dilakukan pendidikan kesehatan. Hal ini merupakan faktor predisposisi dalam perilaku responden dalam melakukan perawatan kaki diabetik.

Faktor pemungkin atau pendukung (enabling) perilaku adalah fasilitas, sarana, atau prasarana yang mendukung atau yang memfasilitasi terjadinya perilaku seseorang atau masyarakat. Misalnya, untuk terjadinya perilaku perawatan kaki diabetik, maka diperlukan perawat atau dokter, fasilitas periksa seperti Puskesmas, Rumah Sakit, Klinik, dan sebagainya. RSUP dr Soeradji Tirtonegoro Klaten mempunyai sarana dan prasarana dalam melakukan pendidikan kesehatan yang dikoordinatori oleh Instalasi PKRS (Promosi Kesehatan Rumah Sakit). Adanya program pendidkan kesehatan melalui leaflet, banner, flow cath, radio sentral dan Sumber Daya Manusia (dokter, perawat dan tenaga kesehatan lainya) yang ada di RSUP dr Soeradji Tirtonegoro Klaten dapat menjadi faktor pendukung perilaku perawatan kaki diabetik.

\section{KESIMPULAN}

Berdasarkan hasil penelitian dan pembahasan, kesimpulan yang dapat ditarik dari penelitian ini yaitu : Tingkat pengetahuan setelah dilakukan pendidikan kesehatan meningkat lebih baik dibandingkan sebelum dilakukan pendidikan kesehatan. Penderita diabetes mellitus kurang mampu dalam merawat kaki sebelum diberikan pendidikan kesehatan. Setelah dilakukan pendidikan kesehatan kemampuan dalam merawat kaki penderita diabetes mellitus meningkat. Ada pengaruh pendidikan kesehatan terhadap perawatan kaki diabetik dengan metode demonstrasi yaitu dapat meningkatkan kemampuan merawat kaki diabetik.

Diharapkan dapat meningkatkan pemahaman dan menambah pengetahuan pasien Diabetes Mellitus tentang perawatan kaki diabetik sehingga bisa melakukan perawatan kaki diabetik dengan tepat. Bagi profesi keperawatan diharapkan dapat menambah keterampilan dan pengetahuan bagi tenaga kesehatan di bidang ilmu keperawatan medikal bedah khususnya perawatan kaki diabetik dengan metode demonstrasi. Rekomendasi penelitian lebih lanjut, $d$ iharapkan untuk penelitan lebih lanjut untuk meneliti tentang perawatan kaki diabetik dengan metode yang berbeda. Melakukan penelitian yang lain yaitu tentang pendidikan kesehatan dan variabel lain yang mempengaruhi terhadap perawatan kaki diabetik pada pasien Diabetes Mellitus. 


\section{DAFTAR PUSTAKA}

Aalaa, O Tabatabaei Malazy. 2012. Nurses Role in Diabetic Foot Prevention and Care. Journal of Diabetis \& Metabolic Disorder. Teheran University, Iran.

Arikunto, 2014, Prosedur Penelitian Suatu Pendekatan Praktik, Rineka Cipta, Jakarta.

Ariyanti, 2014, Hubungan Perawatan Kaki dengan Risiko Ulkus Kaki Diabetes di RS PKU Muhammadiyah Yogyakarta, FK UMY, Jogjakarta.

Asdie, R.H., 2012, Buku Ajar Penyakit Dalam Bagian Ilmu Penyakit Dalam, FK UGM, Jogjakarta.

Buraerah, H., 2010, Analis Faktor Resiko Diabetes Mellitus Tipe 2, Jurnal Ilmiah Nasional FKUI, Jakarta.

Cahyo K., 2011, Model Perencanaan dan Evaluasi Promosi Kesehatan Masyarakat, FKM UNDIP, Semarang.

Damayanti, S., 2015, Buku Ajar Ilmu Endokrin, Diabetes Mellitus, dan Penatalaksanaan Keperawatan, Nuha Medika, Jogjakarta.

Firma Ayu. 2014. Pengaruh Pendidikan Kesehatan terhadap Peningkatan Pengetahuan dan Sikap Penderita Diabetes Mellitus dalam Pencegahan Luka Kaki Diabetik di Desa Mranggen Polokarto. FIK Universitas Muhamadyah Surakarta.

Formosa, C., 2012, The importance of diabetes foot care education in a primary care setting, Journal of Diabetes Nursing, Vol 16 No 10, USA

Kendall, 2013, Sinopsis Organ Sistem Endokrinologi, Karisma Publishing Group. Tangerang Selatan.

Louise H., 2016, Exercise training improves vascular function in adolescents with type 2 diabetes, Journal Physiological Reports, ISSN 2051-817X, USA

Mirza, M., 2012, Mengenal Lebih Mengenai Diabetes Mellitus, Nuha Media, Yogyakarta

Miyauchi, M., 2016, Exercise Therapy for Management of Type 2 Diabetes Mellitus: Superior Efficacy of Activity Monitors over Pedometers, Journal of Diabetes research, Tokai University School of Medicine, Kanagawa, Japan.

Misnadiarly, 2006, Diabetes Mellitus : Ulcer Ganggren, Infeksi. Mengenal Gejala, Menanggulangi, Dan Mencegah Komplikasi, Edisi 1, Pustaka Populer Obor, Jakarta.

Nida Faradisa. 2012. Hubungan Pengetahuan Pasien Diabetes Mellitus Tipe 2 Tentang Risiko Terjadinya Ulkus Diabetik Dengan Kejadian Ulkus Diabetik Di Rsud Dr. Moewardi. FIK Universitas Muhamadyah Surakarta.

Notoatmodjo, S., 2007, Pendidikan Kesehatan Dan Ilmu Perilaku, FKUI, Jakarta.

Nursalam, 2013, Konsep dan Penerapan Metodologi Penelitian Ilmu Keperawatan, Salemba Medika, Jakarta.

Perkeni, 2015, Konsensus Pengendalian dan Pencegahan Diabetes Mellitus Tipe 2 di Indonesia, Jakarta.

Pramesti, D.E., 2014, Perbedaan Pengetahuan tentang Perawatan Kaki Sebelum dan Sesudah Dilakukan Pendidikan Kesehatan di Desa Kedung gading Kecamatan Ringinarum Kabupaten Kendal

Price, S.A., Lorraine, W., 2006, Pathofisiologi, P.A. Wijaya Trans, EGC, Jakarta.

Pusat Data dan Informasi Kemenkes RI, 2012, Gambaran Penyakit tidak Menular Di Rumah Sakit Indonesia, Buletin Jendela Data dan Informasi Kesehatan, Volume 2, Kemenkes RI, Jakarta.

Rakhmat, S., 2011, Pendidikan Kesehatan Dalam Keperawatan, Mulia Medika, Cetakan I, Jogjakarta

Riwidikdo, H., 2007, Statistik Kesehatan Mitra Cendekia, Yogyakarta Rochman, W., 2006, Diabetes Mellitus Pada Usia Lanjut, FKUI, Jakarta.

Sahupala, R.A.M., 2014, Pengaruh Pendidikan Kesehatan Berkala terhadap Kepatuhan Pasien Diabetes Mellitus Tipe 2 dalam Managemen DM Tipe 2 di Poliklinik Endokrin RSUP Wahidin Sudirohusodo Makasar

Soegondo, 2007, Buku Ajar Ilmu Penyakit, Edisi 3, FKUI, Jakarta.

Sugiyono, 2012, Statistik Untuk Penelitian, CV, Alfabeta, Bandung.

Supriyadi, D., Eni, K., Erna S., 2013, Pengaruh Pendidikan Kesehatan Dengan Metode Demonstrasi Terhadap Kemampuan Merawat Kaki Pada Penderita Diabetes Mellitus, Jurnal Management Keperawatan, Volume 01, Jakarta.

Suyono, S., 2006, Kecenderungan Peningkatan Jumlah Penyandang Diabetes dalam Penatalaksanaan Diabetes Mellitus Terpadu, Balai Penerbit FKUI, Jakarta.

Waspadji, S., Sukardi, K., Octaria, M., 2007, Pedoman Diet Diabetes mellitus Sebagai Panduan Bagi Dietisien / Ahli Gizi, Dokter, Mahasiswa, dan Petugas Kesehatan Lain, Penerbit FKUI, Jakarta 
Wendling, S., 2013, The relationship between self-efficacy and diabetic foot self-care, Journal of Clinical and Translational Endocrinology, Saginaw Valley State University, USA

Windasari, N.N., 2014, Pendidikan Kesehatan dalam Meningkatkan Kepatuhan Merawat Kaki pada Pasien Diabetes Mellitus Tipe II. 